ISSN 1392-3196 / e-ISSN 2335-8947

Zemdirbyste-Agriculture, vol. 103, No. 3 (2016), p. 281-288

DOI $10.13080 / \mathrm{z}-\mathrm{a} .2016 .103 .036$

\title{
Distribution of B type trichothecene producing Fusarium species in wheat grain and relation to mycotoxins DON and NIV concentrations
}

\author{
Skaidrė SUPRONIENĖ, Simonas SAKALAUSKAS, Audronė MANKEVIČIENĖ, \\ Karolina BARČAUSKAITE், Akvilè JONAVIČIENE்
}

Institute of Agriculture, Lithuanian Research Centre for Agriculture and Forestry

Instituto 1, Akademija, Kèdainiai distr., Lithuania

E-mail: skaidre@1zi.lt

\begin{abstract}
Fusarium head blight (FHB) is one of the most important cereal diseases causing yield losses and reducing its quality. B type trichothecenes (TRI) deoxynivalenol (DON) and nivalenol (NIV) are the main mycotoxins associated with FHB of wheat and other small-grain cereals. Usually, a particular Fusarium strain is able to produce only one type of $\mathrm{B}$ trichothecene. The detection of gene for NIV, DON and its acetylated derivatives 3-acetyldeoxynivalenol $(3 \mathrm{ADON})$ or 15 -acetyldeoxynivalenol (15ADON) production is used for detection of FHB pathogens in plant material and their chemotyping.

The current study presents the distribution of DON and NIV mycotoxins and their potential producers in Lithuanian wheat grain grown in 2013 and 2014. Grain samples of spring wheat (114) and winter wheat (30) were collected from 49 farms situated in 12 administrative districts of Lithuania. Fusarium species were identified and quantified by the morphological and quantitative polymerase chain reaction (qPCR) techniques. DON concentrations were estimated by the enzyme-linked immunosorbent assay (ELISA) in all collected grain samples and NIV using ultra performance liquid chromatography coupled with mass spectrometry (UPLC/MS) in 17 arbitrarily selected samples. F. graminearum, F. culmorum and F. poae were identified as species capable of producing mycotoxins DON and NIV in wheat grain. The highest DON quantities were identified in the grain of spring wheat grown in 2013 and this was clearly linked to $F$. graminearum DNA quantities $(r=0.783, p<0.01)$. $F$. poae stood out as a potential NIV producer in the grain of Lithuania-grown wheat, since a positive correlation $(r=0.62, p<0.01)$ between the quantities of $F$. poae DNA and NIV concentrations was established. F. culmorum was detected in unexpectedly small quantities in wheat grain and was found to be the potential producer of DON, but not NIV.
\end{abstract}

Key words: chemotype, Fusarium graminearum, Fusarium poae, qPCR, UPLC/MS.

\section{Introduction}

Fusarium head blight (FHB) of small-grain cereals is an important issue in all cereal growing regions due to its relation to reduced yield quality and quantity (Foroud, Eudes, 2009; Wegulo, 2012; Becher et al., 2013; Gilbert, Haber, 2013; Matny, 2015). In Northern Europe, FHB is mostly associated with Fusarium graminearum infections, but species of F. culmorum, F. avenaceum, F. cerealis, $F$. poae, Microdochium nivale and some other less significant ones are also known to contribute to manifestations of this disease (Parry et al., 1995; Waalwijk et al., 2003; Yli-Mattila, 2010; Nielsen et al., 2011; Parikka et al., 2012). In Lithuania, FHB used to pose a minimal threat to cereals and F. graminearum was nearly absent until 2012 (Mačkinaite et al., 2006; Supronienè et al., 2010), when the disease reached epidemic scale and since then has persisted as the major problem in cereals, especially in spring wheat.
FHB is usually closely interlinked with the accumulation of mycotoxins DON and NIV (Becher et al., 2013). Not all the FHB-causing species produce B type trichothecenes (TRI) - this ability is restricted to $F$. graminearum, $F$. culmorum, $F$. cerealis, $F$. poae and $F$. equiseti. Of these species $F$. graminearum and F. culmorum are known to produce both DON and NIV, while others are associated only with NIV contaminated grain (Bottalico, Perrone, 2002; Moss, Thrane, 2004; Yli-Mattila, 2010). Chemotype characterization of the $F$. graminearum and $F$. culmorum has been used for determination of their capacity to produce NIV, DON and its acetylated derivatives 3-acetyldeoxynivalenol (3ADON) or 15-acetyldeoxynivalenol (15ADON) (Desjardins, 2006).

DON is found in higher concentrations and therefore is seen as a bigger threat to food safety than NIV 
(Bottalico, Perrone 2002; Desjardins, 2006). Naturally, DON contamination of grain and its producers have been receiving more attention than NIV and its producers. Several studies on this issue have revealed that DON contamination is common in Lithuania-grown wheat, but concentrations usually did not exceed critical $1250 \mu \mathrm{g} \mathrm{kg}^{-1}$ up until 2012, when 8 samples with DON concentrations with two to seven times $\left(2150-8845 \mu \mathrm{g} \mathrm{kg}{ }^{-1}\right)$ over the permissible limit were detected (Mankevičienè et al., 2007; 2011; 2014).

The research on NIV in Lithuania is in quite a different situation: until now, direct detection and quantification of NIV in grain have not been attempted and the study on the presence of potential NIV producer in wheat has indicated that a very minor part $(<1 \%)$ of overall $F$. graminearum and no part of $F$. culmorum / F. cerealis could contribute to possible wheat contamination with this mycotoxin (Suproniene et al., 2016). Of the other Fusarium species known to produce NIV, F poae is annually recovered from Lithuania-grown wheat grain in significant quantities (Mačkinaitè et al., 2006; Sakalauskas et al., 2014). The potential of $F$. poae to produce NIV cannot be determined by qPCR methods developed for quantification of potential B-type TRI producing $F$. graminearum, $F$. culmorum, F. cerealis and F. pseudograminearum (Ward et al., 2002; Nielsen et al., 2012). Therefore in our study possible correlational ties between the presence of $F$. poae DNA and NIV in wheat grain had to be performed by separate analyses.

With the ongoing FHB epidemic in the fields, monitoring of mycotoxins and their sources in grain has become as important as never before. The aim of this study was to evaluate the distribution of B type trichothecenes (TRI) producing Fusarium species in wheat grain and their relation to mycotoxins DON and NIV contamination.

\section{Material and methods}

Collection of grain samples. Grain samples, including 114 of spring wheat and 30 of winter wheat were collected in 49 commercial fields all over Lithuania in 2013 and 2014 (Fig. 1). Grain samples of $1.0 \mathrm{~kg}$ were taken after harvesting and sub-samples were stored in plastic jars in a freezer at $-20^{\circ} \mathrm{C}$ until analysis.

Grain infection with Fusarium fungi. Fusarium species capable of producing B type trichothecenes (TRI) mycotoxins in grain were detected by plating surface sterilized wheat grain on potato dextrose agar (PDA) ("Merck", Germany) and subsequent visual and microscopic analysis of morphological features according to Leslie et al. (2006).

Deoxynivalenol (DON) analysis. DON content in grain was estimated by a competitive direct enzymelinked immunosorbent assay (CD-ELISA) method (Wilkinson et al., 1992). Quantitative test kits Veratox ${ }^{\circledR}$ ("Neogen", UK) were used for the analysis. The optical densities of the samples and controls from the standard curve were estimated by a photometer Multiskan Ascent (Thermo Electron Corp., Finland) using a filter of $650 \mathrm{~nm}$.
Measured absorbances were automatically converted into mycotoxin concentration $\mu \mathrm{g} \mathrm{kg}^{-1}$. Since the method's limit of detection is $100 \mu \mathrm{g} \mathrm{kg}^{-1} \mathrm{DON}$, samples with less than $100 \mu \mathrm{g} \mathrm{kg}^{-1} \mathrm{DON}$ were regarded as negative. All the analyses were duplicated.

Nivalenol (NIV) detection and quantification by ultra performance liquid chromatography coupled with mass spectrometry (UPLC/MS). A total of 17 samples were arbitrarily selected for NIV analyses (Fig. 1). The samples were divided into four groups: group 1 - no NIV chemotype $F$. graminearum DNA, no internal $F$. poae infection (negative control group); group 2 - positive internal $F$. poae infection, but no NIV chemotype F. graminearum DNA; group 3 - positive NIV chemotype $F$. graminearum DNA, but no internal $F$. poae infection; group 4 - positive both NIV chemotype $F$. graminearum DNA and internal $F$. poae infection. Chemotype incidence in wheat grain samples has been previously presented by Suproniene et al. (2016).

For NIV extraction $3 \mathrm{~g}$ of homogenized grain was mixed with $12 \mathrm{~mL}$ acetonitrile - water (84:16) and shaken on an orbital shaker at $225 \mathrm{rpm}$ for $90 \mathrm{~min}$ at room temperature. $6 \mathrm{~mL}$ of the extract was filtered through paper filter (Whatmann No. 1), extracted through MycoSep ${ }^{\circledR} 230$ Niv push through clean-up column (Rommer Labs Incorp., Austria), $3 \mathrm{~mL}$ transferred into two $2 \mathrm{~mL}$ Eppendorf tubes $(1.5 \mathrm{~mL}$ each) and evaporated to dryness in a centrifugal evaporator at $30^{\circ} \mathrm{C} 6000$ $\mathrm{rpm}$. The residue was reconstituted in $1 \mathrm{~mL}(2 \times 0.5 \mathrm{~mL}$ combined into single sample) $\mathrm{ddH}_{2} \mathrm{O}$, filtered through $0.22 \mu \mathrm{m}$ nylon syringe filter and subjected to UPLC/ MS analysis. NIV separation was carried out using ultra high performance liquid chromatography ACQUITY UPLC H-Class CM Core System ("Waters", USA) coupled with a mass spectrometry detector Xevo G2-XS QTof ("Waters", USA). Chromatographic separations were performed on a reversed-phase C18 column (50 $\times 2.1 \mathrm{~mm}$ inner diameter, particle size $1.7 \mu \mathrm{m}$ ). For chromatographic separation of NIV two mobile phase components were used: $\mathrm{A}$ - water with $0.1 \%$ formic acid and $\mathrm{B}-$ pure LC/MS grade acetonitrile. The flow rate

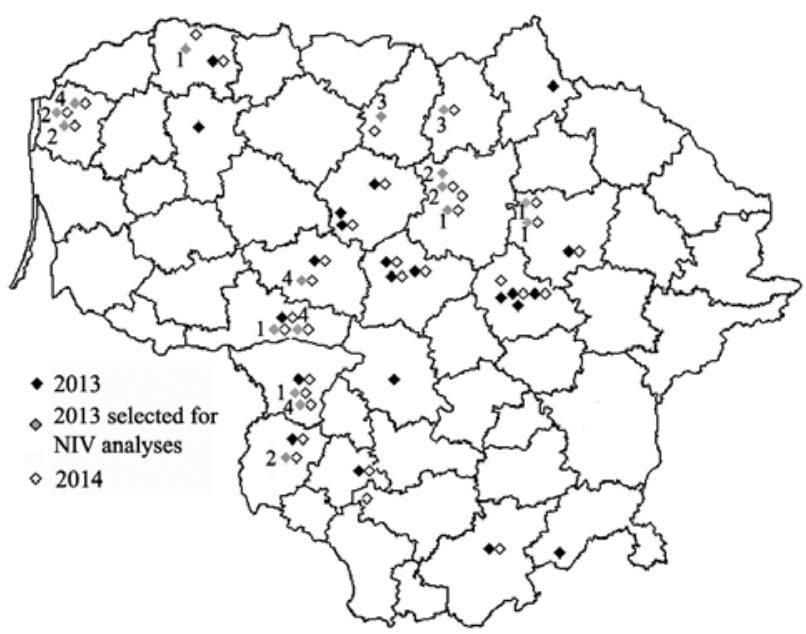

Figure 1. Grain sample collection sites in 2013 and 2014 
was set to $0.5 \mathrm{ml} \mathrm{min}{ }^{-1}$, the injection volume was $10 \mu 1$. Binary gradient was as follows: 0 min $1 \% \mathrm{~B}, 3.0 \mathrm{~min} 50 \%$ B, $3.1 \mathrm{~min} 95 \% \mathrm{~B}$ and hold $95 \% \mathrm{~B}$ to $3.6 \mathrm{~min}, 3.7 \mathrm{~min}$ back to beginning at $1 \% \mathrm{~B}$ and hold to $5 \mathrm{~min}$.

Mass spectrometer was used with negative electro-spray ionization (ESI)-mode with the following settings: source temperature $-120^{\circ} \mathrm{C}$, desolvation temperature $-650^{\circ} \mathrm{C}$, desolvation gas flow $-1000 \mathrm{Lh}^{-1}$, cone gas flow $-100 \mathrm{Lh}^{-1}$, capillary voltage $-1 \mathrm{kV}$, cone voltage $-40 \mathrm{~V}$, collision energy $-6 \mathrm{~V}$. System control was carried out using software Masslynx V4.1. Quantitative analysis of NIV was applied in MS resolution ESI mode. NIV was identified by retention time and m:z ratio. NIV concentration in wheat grain was calculated using NIV standard solution calibration curve $\left(R^{2}=0.996\right)$, in which tenfold NIV dilutions with concentrations 0.01 to $100 \mathrm{ng} \mathrm{mL}^{-1}$ were used.

DNA extraction. $10 \mathrm{~g}$ of each grain sample was ground to a fine powder in liquid nitrogen using a ball mill. DNA was extracted from $0.1 \mathrm{~g}$ of homogenized grain using FastDNA Kit (MP Biomedicals, Germany), DNA concentration was measured by Biophotometer (Eppendorf, Germany) and by electrophoresis in $1 \%$ agarose gel with MassRuller DNA Ladder Mix (Thermo Fisher Scientific, Lithuania) as a standard.

$$
\text { Quantification of Fusarium }
$$

poae DNA. Primers FpoaeA51 fwd (ACCGAATCTCAACTCCGCTTT) and FpoaeA98 rev (GTCTGTCAAGCATGTTAGCACAAGT) were used for quantification of $F$. poae DNA in grain samples (Nicolaisen et al., 2009). DNA of pure culture $F$. poae fungus (verified by qPCR with the same primers) was used for standard curve dilution series $\left(R^{2}=0.987\right)$. Wheat leaf DNA was used for adjustment of fungal DNA quantity in each grain sample (Nicolaisen et al., 2009). qPCR was done in $12.5 \mu \mathrm{L}$ total volume: $6.25 \mu \mathrm{L} 2 \times$ SYBR Green PCR Master Mix (Applied Biosystems, USA), $300 \mathrm{nM}$ of forward and reverse primers, $0.4 \mu \mathrm{g} \mu \mathrm{L}^{-1}$ bovine serum albumin (BSA) (Thermo Fisher Scientific, Lithuania) and $2.5 \mu \mathrm{L}$ template DNA. Samples were duplicated. Reactions were carried out on the 7900HT Sequence Detection System (Applied Biosystems, USA). Cycling protocol: $2 \mathrm{~min}$ at $50^{\circ} \mathrm{C}$ and $95^{\circ} \mathrm{C}$ for $10 \mathrm{~min}$; followed by 40 cycles with $95^{\circ} \mathrm{C}$ for $15 \mathrm{~s}$ and $62^{\circ} \mathrm{C}$ for $1 \mathrm{~min}$ followed by dissociation curve analysis at $60^{\circ} \mathrm{C}$ to $95^{\circ} \mathrm{C}$.

Methods of statistical data analysis. Basic statistics and correlation analysis (Pearson correlation, 2-tailed significance test) were performed using the software IBM SPSS Statistics 20.

\section{Results}

Fusarium infection level in spring wheat grain was twice or more as high as that in winter wheat (Table 1). In wheat grain of both seasonal types $F$. graminearum and $F$. avenaceum were dominant species, followed by F.poae, F. culmorum and F. sporotrichioides, F. tricinctum, $F$. equiseti and some other species were rarely found (only data of potential TRI producers are presented in this paper).

Table 1. Fusarium infection level and deoxynivalenol (DON) concentrations in wheat grain samples in 2013 and 2014

\begin{tabular}{|c|c|c|c|c|c|}
\hline \multirow{2}{*}{ Description } & \multicolumn{4}{|c|}{ Fusarium infected grain $\%$} & \multirow{2}{*}{$\begin{array}{c}\text { DON } \\
\text { concentrations } \\
\mu \mathrm{g} \mathrm{kg}^{-1}\end{array}$} \\
\hline & Fusarium spp. & F. graminearum & F. culmorum & F. poae & \\
\hline \multicolumn{5}{|c|}{ Spring wheat, 2013, $\mathrm{n}=64$} & $\mathrm{n}=64$ \\
\hline Mean & 45.3 & 12.3 & 0.2 & 4.3 & 1163.8 \\
\hline $\mathrm{Sx}$ & 3.4 & 1.6 & 0.1 & 0.7 & 246.8 \\
\hline $\operatorname{Min}(>0)$ & 0.8 & 0.8 & 0.8 & 0.8 & $<$ LOD \\
\hline Max & 96.7 & 49.2 & 1.7 & 25.8 & 10644.0 \\
\hline \multicolumn{5}{|c|}{ Spring wheat, $2014, \mathrm{n}=50$} & $\mathrm{n}=49$ \\
\hline Mean & 40.7 & 15.9 & 0.6 & 12.2 & 322.0 \\
\hline $\mathrm{Sx}$ & 3.6 & 3.1 & 0.2 & 2.5 & 63.7 \\
\hline $\operatorname{Min}(>0)$ & 2.5 & 0.8 & 0.8 & 0.8 & 108.0 \\
\hline Max & 100.0 & 95.0 & 5.8 & 79.2 & 2401.0 \\
\hline \multicolumn{5}{|c|}{ Winter wheat, 2013, $\mathrm{n}=15$} & $\mathrm{n}=11$ \\
\hline Mean & 23.4 & 2.6 & 0.2 & 3.9 & 391.9 \\
\hline $\mathrm{Sx}$ & 6.4 & 0.6 & 0.1 & 0.9 & 72.6 \\
\hline $\operatorname{Min}(>0)$ & 2.5 & 0.8 & 0.8 & 1.6 & 224.0 \\
\hline $\operatorname{Max}$ & 90.0 & 6.7 & 2.0 & 13.3 & 784.6 \\
\hline \multicolumn{5}{|c|}{ Winter wheat, $2014, \mathrm{n}=15$} & $\mathrm{n}=9$ \\
\hline Mean & 8.7 & 1.8 & 0.1 & 1.8 & 374.3 \\
\hline $\mathrm{Sx}$ & 2.7 & 0.7 & 0.1 & 1.0 & 152.2 \\
\hline $\operatorname{Min}(>0)$ & 0.0 & 0.8 & 0.8 & 0.8 & $<$ LOD \\
\hline Max & 39.2 & 8.3 & 0.8 & 14.2 & 1393.0 \\
\hline
\end{tabular}

LOD - limit of detection $\left(100 \mu \mathrm{g} \mathrm{kg}^{-1}\right)$ 
Of the species capable of producing B type TRI (DON and/or NIV), F. graminearum, F. culmorum and $F$. poae were detected in wheat grain. $F$. graminearum and $F$. poae were found in $89 \%$ and F. culmorum - in $35 \%$ of the total spring wheat samples tested. In 2013, infection level of $F$. poae was much lower than that of F. graminearum; however, in 2014 it became comparable. In winter wheat $F$. graminearum was detected in $60 \%$ of the grain samples tested, $F$. poae - in $57 \%$ and F. culmorum - in $17 \%$. In $2013, F$. poae infection level in winter wheat grain was slightly higher than that of F. graminearum (Table 1).

DON was found in $96.7 \%$ of spring wheat and $91.0 \%$ of winter wheat samples tested in 2013 and in $67.3 \%$ of spring wheat and $88.9 \%$ of winter wheat samples in 2014. The average DON concentration

Table 2. Correlations between Fusarium graminearum and F. culmorum infection level, DNA quantities (ng $\mu \mathrm{g}^{-1} \mathrm{plant}^{-}$ DNA) and deoxynivalenol (DON) concentrations in spring wheat grain in 2013 and $2014(\mathrm{n}=114)$

\begin{tabular}{|c|c|c|c|c|}
\hline Target & $\begin{array}{c}\text { F. graminearum } \\
\%\end{array}$ & $\begin{array}{c}\text { F. culmorum } \\
\%\end{array}$ & $\begin{array}{l}\text { F. graminearum } \\
\text { DNA }\end{array}$ & $\begin{array}{l}\text { F. culmorum } \\
\text { DNA }\end{array}$ \\
\hline F. culmorum \% & $0.476 * *$ & & & \\
\hline F. graminearum DNA & $0.294 * *$ & 0.017 & & \\
\hline F. culmorum DNA & 0.094 & 0.004 & $0.414^{* *}$ & \\
\hline $\mathrm{DON} \mu \mathrm{g} \mathrm{kg}^{-1}$ & $0.351 * *$ & -0.006 & $0.783 * *$ & $0.401 * *$ \\
\hline
\end{tabular}

** - significant at the 0.01 level

in spring wheat in 2013 was $1163.8 \mu \mathrm{g} \mathrm{kg} \mathrm{kg}^{-1}$ (0 to $\left.10644.0 \mu \mathrm{g} \mathrm{kg}^{-1}\right)$, about three times higher than in 2014 (average of $322.0 \mu \mathrm{g} \mathrm{kg}^{-1}$ ) or in winter wheat (average of $391.9 \mu \mathrm{g} \mathrm{kg}^{-1}$ in 2013 and $374.3 \mu \mathrm{g} \mathrm{kg}^{-1}$ in 2014). The DNA quantities of $F$. graminearum and $F$. culmorum are presented in Suproniene et al. (2016), where large variation between and within spring and winter grain samples is shown. Correlations between DNA quantity of these two species and DON are stronger than between internal grain infection determined by plating and DON (Table 2).

F. poae DNA quantities in positive samples ranged from 1.9 to $148.1 \mu \mathrm{g} \mathrm{kg}^{-1}$ wheat DNA. Five of the 17 tested grain samples were found to be free of $F$. poae. Variable quantities of $F$. poae DNA were detected in all samples from which $F$. poae was isolated during internal grain mycobiota survey. Five samples that were deemed free of $F$. poae in internal grain infection contained low quantities of $F$. poae DNA (Fig. 2 A, B).

All but four samples were found to be NIV positive (Fig. $2 \mathrm{C}$ ). In two of these negative samples no $F$. poae DNA was detected, the other two contained very small amounts of the $F$. poae DNA. Three of the four NIV negative samples were found to be $F$. poae-free in internal grain mycobiota survey. NIV concentrations were in the range between 0.5 and $63.5 \mu \mathrm{g} \mathrm{kg}^{-1}$ wheat grain. The highest NIV concentrations were detected in samples 29 and 45, which contained both $F$. poae and NIV chemotype $F$. graminearum DNA. Samples 21, 47 and 57, that contained somewhat larger quantities of NIV are associated with $F$. poae but not NIV chemotype $F$. graminearum. Only two samples of the supposedly control group 1, namely 20 and 61 , were found to be free of $F$. poae DNA and NIV. The other four samples of this group contained either NIV (sample 9), or $F$. poae DNA (sample 12), or both (samples 41 and 47).

Positive correlation $(r=0.81, p<0.01)$ between $F$. poae DNA quantity and NIV concentration in grain was observed. No significant correlation was identified between internal $F$. poae grain infection determined by classic microbiology methods and neither $F$. poae DNA quantity $(r=0.18)$ nor NIV concentration $(r=-0.08)$ was detected (Table 4).

\section{Discussion}

This study, supported by the results from Suproniene et al. (2016), concluded that two Fusarium species, namely $F$. graminearum and $F$. poae, are the key producers of DON and NIV mycotoxins in Lithuania-grown wheat. The third potential TRI producer F. culmorum was found to be a rather occasional or secondary pathogen to $F$. graminearum rather than the main cause of FHB epidemics in the fields.

Despite somewhat similar incidence levels in grain, $F$. graminearum should be viewed as far greater threat to wheat than $F$. poae. This is partly due to limitations of internal grain mycobiota surveys, which do not represent the actual amounts of fungus in grain. As a result, $F$. graminearum DNA quantities (Suproniene et al., 2016) and subsequently DON concentrations in grain tend to be times higher than those of $F$. poae and NIV, even when percentage of infected grain is very similar. Differences in toxin production in grain could be related to certain fungal species or strain capacity and their special need for environmental conditions (Leslie et al., 2006; Stenglein, 2009). At least partly this should be due to host susceptibility. Nielsen et al. (2011) indicated clear differences in the ratio between the NIV producers and the crop species: the F. graminearum or F. culmorum: $F$. poae ratio in wheat varies from 10:1 to $100: 1$, whereas in barley - from 2:1 to $1: 3$.

Meteorological conditions are another important issue for host colonization and mycotoxin production. $F$. graminearum incidence in grain was comparable in 2013 and 2014, but DON concentrations in grain were significantly lower in a cooler summer of 2014. NIV quantities have not been estimated in grain samples 
A $\quad$ Internal $F$. poae infection level \%

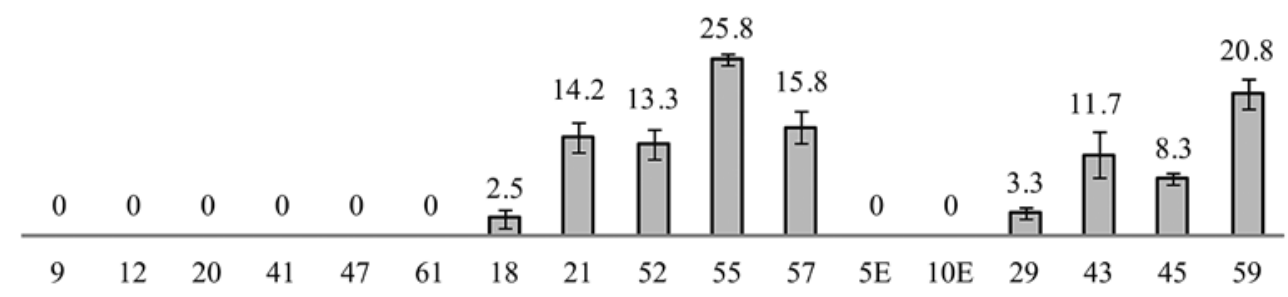

B $\quad \boldsymbol{\square} F$. poae DNA quantity, $\mathrm{ng}^{\mu \mathrm{g}^{-1}}$ plant DNA

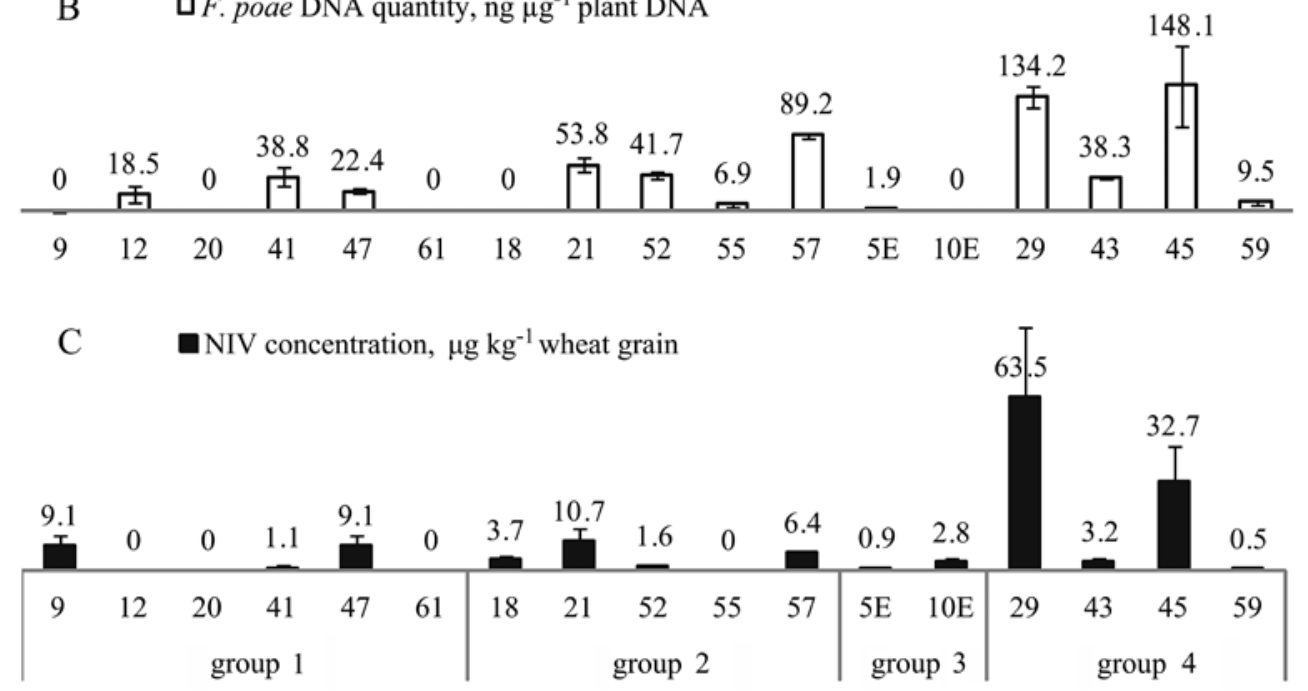

Note. Group 1 - no NIV chemotype F. graminearum DNA and no internal F. poae infection; group 2 - positive internal $F$. poae infection, but no NIV chemotype $F$. graminearum DNA; group 3 - positive NIV chemotype $F$. graminearum DNA, but no internal $F$. poae infection; group 4 - positive both NIV chemotype $F$. graminearum DNA and internal F. poae infection

Figure 2. Results of internal Fusarium poae infection, F. poae DNA quantity and nivalenol (NIV) concentrations in the tested samples

Table 4. Correlations between Fusarium poae DNA quantities, internal F. poae grain infection and nivalenol (NIV) concentrations

\begin{tabular}{lcc}
\hline Target & F. poae DNA quantity & NIV concentration \\
\hline NIV concentration & $0.81^{* *}$ & \\
Internal F. poae grain infection & 0.18 & -0.08 \\
\hline
\end{tabular}

** - significant at the 0.01 level

harvested in 2014. Since most of NIV is clearly produced by $F$. poae, mycotoxin quantities in grain could have been higher, as $F$. poae is a well-established pathogen in Nordic countries and is able to thrive in relatively cool summers (Stenglein, 2009).

In the present study we focused on $F$. poae as one of the most frequently isolated FHB pathogens (Xu et al., 2005; Mankevičienè et al., 2007; Yli-Mattila et al., 2008; Stenglein, 2009; Sakalauskas et al., 2014). Previously we have determined that the other supposedly major wheat pathogens F. culmorum / F. cerealis play an insignificant role in production of DON and are not a producer of NIV in wheat (Suproniene et al., 2016). This effectively leaves only $F$. poae as an alternative source of NIV - the other FHB causing Fusarium species either do not produce B-type TRI or are found in negligible numbers (Mankevičienè et al., 2007; Supronienè et al., 2012; Sakalauskas et al., 2014). F. poae is more widespread in cereals in Northern Europe and some studies show correlation between F.poae and NIV presence in these crops (Bottalico, Perrone, 2002; Nielsen et al., 2011). Our study indicates that $F$. poae infection and NIV accumulation do not pose an immediate threat to Lithuanian wheat. NIV quantities in grain were times lower than those of DON and went well under the acceptable limit of $1250 \mu \mathrm{g} \mathrm{kg}^{-1}$. According to manufacturer description, the output of MycoSep ${ }^{\circledR} 230$ Niv push through clean-up column should be no less than $80 \%$ of the initial mycotoxin concentration. Considering results obtained, even if $20 \%$ of mycotoxin is lost during sample preparation, the NIV concentrations remain quite low (Fig. 2). 
Only one NIV chemotype $F$. graminearum positive sample 10E (group 3) did not contain F. poae DNA. This indicates at least two potential NIV contamination sources in grain. In addition, sample 9 (group 1) contained NIV (mycotoxin) but no F. poae or NIV chemotype $F$. graminearum. Since the primers used for the detection of NIV chemotype DNA should also detect NIV chemotype of species F. culmorum, F. cerealis and $F$. graminearum (Nielsen et al., 2012), the NIV in sample 9 must be associated with yet another species, capable of producing NIV. The highest NIV concentration and the highest $F$. poae DNA quantity coincided to be in the same samples 29 and 45 of group 4 . This means that the main actual source of NIV in those samples cannot be pointed out accurately as it is NIV chemotype F. graminearum DNA positive as well. Other samples with the highest NIV concentrations 21, 47 and 57 were found to be free of NIV chemotype $F$. graminearum DNA and also had some of the highest $F$. poae DNA quantities (Fig. 2).

Absence of correlation between $F$. poae DNA or NIV quantities in grain and the incidence of $F$. poae in grain obtained by agar plating methods demonstrate the limits of these methods in detection of potential mycotoxin producers. But there was one exception in our study: sample 18 was found to be free of $F$. poae DNA, but not of NIV. Sample group 2 to which it belongs contains grain samples with internal $F$. poae infection. The determination of $F$. poae infection by qPCR assay by default should be much more accurate than by plating on agar medium, but peculiarly it was not in this case. Misidentification of the fungal cultures growing from the plated seeds is probable, but then $F$. poae should have been confused with Fusarium species capable of producing NIV, of which none morphologically is too similar to F. poae (Moss, Thrane, 2004; Jestoi et al., 2008).

\section{Conclusions}

1. In 2013 and 2014, the main Fusarium species capable of producing B type trichothecenes (TRI) in Lithuania-grown wheat were $F$. graminearum, $F$. poae and $F$. culmorum, infecting on average 13.7, 8.2 and 0.4 $\%$ of spring wheat and 2.2, 2.9 and $0.2 \%$ of winter wheat grain, respectively.

2 . The DNA quantity of $F$. graminearum and $F$. culmorum in grain had stronger correlations with deoxynivalenol (DON) quantity $(p<0.01)$ than the internal grain infection; this demonstrates the advantages of qPCR technique over the morphological plating method.

The positive correlation determined between mycotoxin nivalenol (NIV) and $F$. poae DNA quantities in grain $\left(r=0.81^{* *}\right)$ indicates that Lithuania-grown wheat is the source of at least two NIV producers $-F$. poae and F. graminearum.

\section{Acknowledgements}

The study was funded by the Lithuanian Research Council through the National Research Programme "Healthy and Safe Food", grant No. SVE09/2014 (TRICHEMOTIPAI).

Received 22042016

Accepted 26072016

\section{References}

Becher R., Miedaner T., Wirsel S. G. R. 2013. Biology, diversity and management of FHB-causing Fusarium species in small-grain cereals. Kempken. F. (ed.). The Mycota. XI. Agricultural Applications ( $2^{\text {nd }}$ ed.). Berlin, Germany, p. $199-241$ http://dx.doi.org/10.1007/978-3-642-36821-9_8

Bottalico A., Perrone G. 2002. Toxigenic Fusarium species and mycotoxins associated with head blight in small-grain cereals in Europe. European Journal of Plant Pathology, 108: 611-624 http://dx.doi.org/10.1023/A:1020635214971

Desjardins A. E. 2006. Fusarium mycotoxins, chemistry, genetics, and biology. American Phytopathological Society. St. Paul, USA, 268 p.

Foroud N. A., Eudes F. 2009. Trichothecenes in cereal grains. International Journal of Molecular Sciences, 10: 147-173 http://dx.doi.org/10.3390/ijms10010147

Gilbert J., Haber S. 2013. Overview of some recent research developments in fusarium head blight of wheat. Canadian Journal of Plant Pathology, 35 (2): 149-174 http://dx.doi.org/10.1080/07060661.2013.772921

Jestoi M. N., Paavanen-Huhtala S., Parikka P., Yli-Mattila T. 2008. In vitro and in vivo mycotoxin production of Fusarium species isolated from Finnish grains. Archives of Phytopathology and Plant Protection, 41: 545-558 http://dx.doi.org/10.1080/03235400600881547

Leslie J. F., Summerell B. A., Bullock S. 2006. The Fusarium laboratory manual. Ames, USA, 388 p. http://dx.doi.org/10.1002/9780470278376

Mačkinaitè R., Kačergius A., Lugauskas A., Repečkienė R. 2006. Contamination of cereal grain by Fusarium micromycetes and their mycotoxins under Lithuanian climatic conditions. Ekologija, 3: 71-79

Mankevičienė A., Butkutė B., Dabkevičius Z., Supronienė S. 2007. Fusarium mycotoxins in Lithuanian cereals from the 2004-2005 harvests. Annals of Agricultural and Environmental Medicine, 14: 103-107

Mankevičienė A., Butkutė B., Gaurilčikienė I., Dabkevičius Z., Supronienè S. 2011. Risk assessment of Fusarium mycotoxins in Lithuanian small cereal grains. Food Control, 22: 970-976 http://dx.doi.org/10.1016/j.foodcont.2010.12.004

Mankevičienė A., Jablonskytė-Raščè D., Maikštenienė S. 2014. Occurrence of mycotoxins in spelt and common wheat grain and their products. Food Additives and Contaminants. Part A, 31 (1): 132-138 http://dx.doi.org/10.1080/19440049.2013.861614

Matny O. N. 2015. Fusarium head blight and crown rot on wheat and barley: losses and health risks. Advances in Plants and Agriculture Research, 2 (1): 00039 http://dx.doi.org/10.15406/apar.2015.02.00039 
Moss M. O., Thrane H. 2004. Fusarium taxonomy with relation to trichothecene formation. Toxicology Letters, 153: $23-28$

http://dx.doi.org/10.1016/j.toxlet.2004.04.021

Nicolaisen M., Suproniene S., Nielsen L. K., Lazzaro I., Spliid N. H., Justesen A. F. 2009. Real-time PCR for quantification of eleven individual Fusarium species in cereals. Journal of Microbiological Methods, 76: $234-240$

http://dx.doi.org/10.1016/j.mimet.2008.10.016

Nielsen L. K., Jensen J. D., Nielsen G. C., Jensen J. E., Spliid N. H., Thomsen I. K., Justesen A. F., Collinge D. B., Jorgensen L. N. 2011. Fusarium head blight of cereals in Denmark: species complex and related mycotoxins. Phytopathology, 101: 960-969 http://dx.doi.org/10.1094/PHYTO-07-10-0188

Nielsen L. K., Jensen J. D., Rodríguez A., Jørgensen L. N., Justesen A. F. 2012. TRI12 based quantitative real-time PCR assays reveal the distribution of trichothecene genotypes of $F$. graminearum and $F$. culmorum isolates in Danish small grain cereals. International Journal of Food Microbiology, 157: 384-392 http://dx.doi.org/10.1016/j.ijfoodmicro.2012.06.010

Parikka P., Hakala K., Tiilikkala K. 2012. Expected shifts in Fusarium species' composition on cereal grain in Northern Europe due to climatic change. Food Additives and Contaminants: Part A, 29 (10): 1543-1555 http://dx.doi.org/10.1080/19440049.2012.680613

Parry D. W., Jenkinson P., McLeod L. 1995. Fusarium ear blight (scab) in small grain cereals - a review. Plant Pathology, 44: $207-238$ http://dx.doi.org/10.1111/j.1365-3059.1995.tb02773.x

Sakalauskas S., Stumbrienè K., Supronienė S., Švėgžda P. 2014. Changes in Fusarium Link species composition from Lithuanian wheat grain in years 2005-2007 to 2011-2013. Proceedings of the Latvia University of Agriculture, 32: 45-50 http://dx.doi.org/10.2478/plua-2014-0013

Stenglein S. A. 2009. Fusarium poae: a pathogen that needs more attention. Journal of Plant Pathology, 91 (1): 25-36

Suproniene S., Justesen A. F., Nicolaisen M., Mankeviciene A., Dabkevicius Z., Semaskiene R., Leistrumaite A. 2010. Distribution of trichothecene and zearalenone producing Fusarium species in grain of different cereal species and cultivars grown under organic farming conditions in Lithuania. Annals of Agricultural and Environmental Medicine, 17: 79-86

Supronienė S., Mankevičienė A., Kadžienė G., Kačergius A., Feiza V., Feizienė D., Semaškienė R., Dabkevičius Z., Tamošiūnas K. 2012. The impact of tillage and fertilization on Fusarium infection and mycotoxin production in wheat grains. Zemdirbyste-Agriculture, 99 (3): 265-272

Suproniene S., Sakalauskas S., Stumbriene K., Zvirdauskiene R., Svegzda P. 2016. Variances in trichothecene chemotype distribution in Lithuanian wheat grain and within pure culture Fusarium graminearum isolated from the same grain samples. European Journal of Plant Pathology, 144 (2): $371-381$

http://dx.doi.org/10.1007/s10658-015-0774-9
Waalwijk C., Kastelein P., de Vries I., Kerényi Z., van der Lee T., Hesselink T., Köhl J., Kema G. 2003. Major changes in Fusarium spp. in wheat in the Netherlands. European Journal of Plant Pathology, 109 (7): 743-754 http://dx.doi.org/10.1007/978-94-017-1452-5_9

Ward T. J., Bielawski J. P., Kistler H. C., Sullivan E., O'Donnell K. 2002. Ancestral polymorphism and adaptive evolution in the trichothecene mycotoxin gene cluster of phytopathogenic Fusarium. Proceedings of the National Academy of Sciences of the United States of America, 99: 9278-9283 http://dx.doi.org/10.1073/pnas.142307199

Wegulo S. N. 2012. Factors influencing deoxynivalenol accumulation in small grain cereals. Toxins, 4: $1157-1180$ http://dx.doi.org/10.3390/toxins4111157

Wilkinson A. P., Ward C. M., Morgan M. R. A. 1992. Immunological analysis of mycotoxins. Lins-Kens H. F., Jackson J. F. (eds). Plant toxin analysis. Berlin, Germany, p. $185-225$ http://dx.doi.org/10.1007/978-3-662-02783-7_7

Xu X., Parry D., Nicholson P., Thomsett M., Simpson D., Edwards S., Cooke B., Doohan F., Brennan J., Moretti A., Tocco G., Mulè G., Hornok L., Giczey G., Tatnell J. 2005. Predominance and association of pathogenic fungi causing Fusarium ear blight in wheat in four European countries. European Journal of Plant Pathology, 112: 143-154 http://dx.doi.org/10.1007/s10658-005-2446-7

Yli-Mattila T. 2010. Ecology and evolution of toxigenic Fusarium species in cereals in Northern Europe and Asia. Journal of Plant Pathology, 92: 7-18

Yli-Mattila T., Paavanen-Huhtala S., Parikka P., Hietaniemi V., Jestoi M., Gagkaeva T., Sarlin T., Haikara A., Laaksonen S., Rizzo A. 2008. Real-time PCR detection and quantification of Fusarium poae, F. graminearum, $F$. sporotrichioides and $F$. langsethiae as compared to mycotoxin production in grains in Finland and Russia. Archives of Phytopathology and Plant Protection, 41: 243-260 http://dx.doi.org/10.1080/03235400600680659 


\title{
B tipo trichotecenus produkuojančių Fusarium genties grybų pasiskirstymas kviečių grūduose ir ryšys su mikotoksinų DON bei NIV koncentracijomis
}

\author{
S. Supronienè, S. Sakalauskas, A. Mankevičienė, K. Barčauskaitė, A. Jonavičienė \\ Lietuvos agrarinių ir miškų mokslų centro Žemdirbystės institutas
}

\begin{abstract}
Santrauka
Varpų fuzariozė yra viena pagrindinių varpinių javų ligų, mažinančių grūdų derlių ir kokybę. Trichotecenai (TRI) deoksinivalenolis (DON) ir nivalenolis (NIV) yra pagrindiniai mikotoksinai, susiję su kviečių ir kitų smulkiagrūdžių javų varpų fuzarioze. Straipsnyje pateiktas mikotoksinų DON bei NIV ir jų potencialių producentų pasiskirstymas Lietuvoje užaugintų kviečių grūduose 2013 ir 2014 m. Tyrimų laikotarpiu surinkta ir ištirta 114 vasarinių kviečių ir 30 žieminių kviečių grūdų mėginių iš 49-ių ūkių, esančių 12-oje Lietuvos administracinių rajonų. Fusarium rūšys identifikuotos ir kiekybiškai įvertintos morfologiškai ir taikant kiekybinị PGR metodą. DON koncentracijos ịvertintos imunofermentiniu (ELISA) metodu, NIV - taikant efektyviają skysčiu chromatografiją ir masių spektrometriją (UPLC/MS).

Kviečių grūduose kaip potencialios mikotoksinų DON ir NIV producentès identifikuotos F. graminearum, F. culmorum ir F. poae rūšys. Mikotoksino DON kiekis stipriai koreliavo su F. graminearum DNR kiekiu $(r=$ $0,783, p<0,01)$ ir buvo didžiausi 2013 m. užaugintų vasarinių kviečių grūduose. F. poae išryškèjo kaip potenciali mikotoksino NIV producente Lietuvoje užaugintuose kviečiuose, nes nustatyti esminiai koreliaciniai ryšiai $(r=$ $0,62, p<0,01) \operatorname{tarp} F$. poae DNR kiekių ir NIV koncentracijų. F. culmorum rūšies kviečių grūduose aptikta labai mažas kiekis, ir ji pasižymėjo kaip potenciali DON, o ne NIV producentè.
\end{abstract}

Reikšminiai žodžiai: chemotipas, F. graminearum, F. poae, kiekybinė PGR, UPLC/MS.

Please use the following format when citing the article:

Supronienė S., Sakalauskas S., Mankevičienė A., Barčauskaitė K., Jonavičienè A. Distribution of B type trichothecene producing Fusarium species in wheat grain and relation to mycotoxins DON and NIV concentrations. Zemdirbyste-Agriculture, 103 (3): 281-288 DOI 10.13080/z-a.2016.103.036 